\title{
No One is Illegal Between City and Nation ${ }^{1}$
}

\author{
PETER NYERS \\ Department of Political Science, McMaster University
}

ABSTRACT By challenging the state's prerogative to distinguish between insiders and outsiders, citizens and non-citizens, political movements by and in support of migrants and refugees are forcing questions about what criteria, if any, can and should be used to determine who can claim membership in the political community. To illustrate the complexity of this politics this article analyzes the major demand that underscores every campaign undertaken by non-status refugees and migrants in Canada: a program that would allow them to "regularize" their status. Notably, these campaigns are being directed at both the state and city levels of governance. Together, these are two sites in which claims and counter-claims about community, belonging, and citizenship are being made by, for, and against non-status immigrants. In each case, migrant political agency is asserted in places meant to deny, limit, or repress it. The article argues that the significance of these sites is that they allow for nonstatus refugees and migrants themselves to act as mediators or translators between the city and nation, between polis and cosmopolis.

"I'm illegal. So what?"

— T-shirt slogan, “A Day Without Immigrants,” New York City, May 1, 2006

\section{Acts of Non-Citizenship}

This article investigates acts of citizenship by politicized groups of non-status migrants and refugees, and assesses the normative and political challenges they pose to established norms about citizenship, belonging, and political community. Refugees and other migrants with precarious status are emerging as key protagonists in global struggles concerning freedom of movement, social recognition, worker protections, and the right of asylum (McNevin, 2006). In Australia, to take a wellknown case, widespread resistance has been organized both within and outside a country-wide network of asylum-seeker detention centres. Hunger strikes and demonstrations by detainees have been actively supported by citizen movements outside the barbed wire fences, including a 1,000-person convergence on the Woomera detention centre in 2001 during which these fences were torn down. In Canada, over 1,000 non-status Algerians living in Montreal launched a public campaign that successfully pressured the Canadian and Quebec governments to regularize their status (Nyers, 2003). In Egypt, frustrations with the refugee 
determination system provoked over 3,000 Sudanese "closed file" refugees to occupy Mustafa Mahmoud Park and hold a three month sit-in outside the offices of the United Nations High Commission for Refugees in Cairo (FMRS, 2006). In Europe, migrants have organized several "Migrant Assemblies" in order to assert their voices and raise their agendas amidst the din of the "citizen groups" that dominate the voices of the European Social Forum network. Examples of political engagement by refugees and non-status migrants could go on and on, but clearly these acts are becoming increasingly important sites of global/local politics (McNevin, 2006).

The vibrancy and scope of refugee and migrants' rights movements was perhaps demonstrated most dramatically in the Spring of 2006, when undocumented migrants organized massive, record-breaking protests in major American cities. The New York Times (Editorial, 2006) described the events as the result of a "miracle of grassroots mobilization that turned a shadow population into a national movement in less than a month." The public protests culminated in a National Day of Action on May 1, 2006 - a general strike in all but name, variously called "A Day Without Immigrants," the "Great American Boycott," and "the new civil rights movement." The sheer scope of the protests is largely without precedent in American history. The number of people-citizens and non-citizens, documented and undocumented-that took to the streets broke records for public demonstrations in many cities. Conservative estimates counted 600,000 demonstrators marching in the streets of Los Angeles; 400,000 in Chicago; 50,000 in San Francisco and San Jose; 15,000 in Houston; 30,000 across Florida; and so on. Perhaps even more dramatic were the protests not covered by the major media. Small towns like Porterville (California), Yakima (Washington), El Paso (Texas), and Castroville (California)—towns where citizens rarely, if ever, engage in public protest-were witness to public demonstrations by hundreds of undocumented immigrants. While the protests have been criticized for the overuse of American flags and the appeal to American nationalism (e.g. Bauder, 2006), they nonetheless represent an important moment of claim making and rights taking by non-citizens. In this sense, one of the most remarkable elements of the massive protests associated with A Day Without Immigrants is that tens of thousands of protestors took to the streets without any mobilization by established social movement organizations. "People were caught up in the moment," says one migrant rights activist from New York City. ${ }^{2}$

What insights can be gained about citizenship from these "moments" when noncitizens with extremely precarious status assert themselves as political by publicly making claims about rights and membership, freedom and equality? Engin Isin (2008) contrasts the relatively enduring institutions and dispositions of habitus with the temporally focused perspective offered by "acts" of citizenship. He proposes that investigating acts of citizenship involves a "focus on those moments when, regardless of status and substance, subjects constitute themselves as citizens-or, better still, as those to whom the right to have rights is due" (p. 18). This article will examine acts of citizenship with reference to the growing political movement of nonstatus migrants in Canada. While smaller in scope than the campaign in the United States, the movement in Canada has been equally significant in raising a number of challenges for how we understand political community and political subjectivity. The article will discuss the significance of a number of "acts" by the action committees of non-status migrants: acts of self-identification as "non-status"; acts of claim 
making and rights taking in the form of regularization campaigns at both the state and city levels; acts of protest in street rallies, marches, and detention centres. The aim of focusing on this case is to ask some critical questions about acts of citizenship. What are the conditions under which non-status persons can constitute themselves as being political? Does the act of reclaiming the term "non-status" by the political "action committee" of non-status migrants qualify as an act of citizenship? Are acts of autonomy and self-representation also acts of citizenship? What kind of acts of citizenship would allow for no one to be illegal? Taken together, do these various "acts” signal the emergence of a new subjectivity?

To investigate the political movements by non-status migrants means coming to terms with a fundamental disagreement over what counts as political. In Canada, self-organized "action committees" of non-status migrants and refugees have emerged and asserted themselves as political by organizing against detentions and deportations, as well as pressuring the government to regularize their status. However, the action committees are regularly confronted with the problem that the identity conferred on them is one that historically has been excluded from the political domain. Non-status people not only lack the full range of citizenship rights, but they are also denied the opportunity to express themselves as political beings. Their banishment from the political, moreover, is not merely the result of national and international laws that prohibit (or make it risky for) refugees or non-citizens to act politically. The problem is as much conceptual as it is legal: it turns on the fact that historically citizenship has been the identity through which claims to political being are enacted.

Faced with the myriad ways in which non-status people have been spoken for and silenced, the aim of this article is similar to that of Moulier-Boutang's (2001), who has urged us "to seize the silences, the refusals, and the flight as something active" (p. 227). How exactly to accomplish this ambitious task may always remain elusive. However, surely an important part of the answer must include a consideration of the role that "voice" plays in the constitution of political subjectivity. To publicly selfidentify as "non-status" is to engage in a political act, or better-an act of political subjectification. What the action committees of non-status refugees and migrants illuminate is that the claim "I am non-status" is not just a moral plea. It is rather a declaration that is generative of a political subjectivity. In a deeply paradoxical way, to self-identify as a non-status person is to engage in an act of citizenship.

\section{Vocalizing Acts of Citizenship}

To act is to put something into motion, to create something new. But the "problem of beginning," as Said (2004) put it, is always the "beginning of the problem." At the origin of Western political thought is the work of Aristotle, the first political scientist, who placed certain vocal acts at the centre of his theory of the political. To be sure, questions about the political seem unavoidably intertwined with questions about voice. Aristotle emphasizes the deeply political dimensions of voice, and provides an account of the political that begins with a partitioning of different kinds of voices. In the opening passages of Aristotle's Politics, a crucial distinction is drawn between the voice (phone) that can indicate pleasure or pain, and the voice (logos) that can articulate the just and unjust. For Aristotle, the former is shared by 
both animals and humans; the latter is the sole domain of humans. It is this latter form of speech that allows one to say "I have been wronged" introducing a standard of judgment that allows for the space of the political to emerge (Dolar, 2006, pp. 105-106).

Thus politics has emerged as a practice in which the use of voice makes it possible to perform certain acts. Key among these are acts of citizenship. Isin (2008) argues that acts of citizenship can be authored or anonymous, intended or accidental, individual or collective. In this account of citizenship what counts is not the subject's status (citizen, refugee, non-status migrant) but the act itself. Thinking about citizenship in this way makes one attentive to the enactments of citizenship, how it is performed and negotiated. Traditionally citizenship has been investigated in terms of rights and responsibilities, their substantive content or depth, and the extent to which that are (and are not) distributed across society. This approach, Isin (2008) complains, is unsuitable for interpreting acts of citizenship. "They arrive too late," he says, "because the actors of extent, content, and depth are already produced" (p. 37). For Isin, acts produce actors/subjects: "acts produce actors that do not exist before acts.” Acts of citizenship, therefore, produce citizens and their others: strangers, outsiders, aliens. Investigating "acts of citizenship" demands a rethinking of many of the assumptions, dispositions, biases, and fascinations of modern social and political thought: the privileging of order over change, action over acts, the enduring over the momentary, certainty over contingency, planned over accidental, and so on.

Isin's account of citizenship is part of a growing movement within citizenship studies that criticizes the exclusions rendered by the acceptance of formal citizenship as a precondition for political voice. It is becoming increasingly common to hear arguments that criteria for inclusion should rely less on formal membership than on the principal that "all affected" people should be included in the demos. It follows that the right to vote in elections should be granted to resident non-citizens (Beckman, 2006). To be able to vote in democratic elections is an important achievement for non-citizens, as it recognizes their autonomy, personhood, and capacity to assert themselves as political beings. However, acts of voting should not be taken as the end point for acts of citizenship. What other possibilities exist for the enactment of political voice? As Dolar (2006, p. 202) points out, etymologically "to vote" draws on the Latin words for "wish" and "pledge" and bears no relation to the word vox, voice. The relationship of voice to the political involves a much more complicated set of issues than simply the right to vote. What is at stake is the model by which the political community constitutes its subjects, audiences, and spaces.

This raises an important aspect of political community that is often unappreciated and undertheorized-that the political community is also an aesthetic community. Constituting the world is always an aesthetic activity, in that it involves a framing of the given, of what can be perceived and seen, heard, and heeded. There is what Jacques Rancière calls the "partition of the sensible" that orders and polices what is visible, what can be said, who can speak. This partitioning is practiced in a highly uneven fashion, and so it is important to emphasize that this is a politics of aesthetics. Non-status migrants are disqualified from sharing the stage with citizens as (political) actors. The equation between citizenship and the political creates an aesthetic order where non-status migrants are variously seen as a threat, a risk, or a victim. They are rarely perceived as agents, actors, participants, or subjects capable of making claims and demanding rights. 
Rancière's project is to enact a redistribution of the perceptible, of what can be said and seen. He bases this project on the idea of radical equality. For him, the political involves a miscount of equality. Politics occurs during those moments when those who "do not count," who have "no part" in the recognized social order, make a claim to be counted. These claims appear as an interruption of the established speaking order which elevates citizenship to holding a near monopoly of speech acts. In contrast to the optimism for rational and inclusive dialogue that democratic theorists look for in (global) civil society, Rancière's emphasis on interruption and disagreement as foundational political moments is worth reflecting upon and has important resonances with the dissonant speech acts of non-status migrant politics (McNevin, 2006; Nyers, 2006; Panagia, 2006, pp. 119-124; Rancière, 1999). Rancière rejects Kantian aesthetics in favour of the Burkean sublime, albeit with a significant change in emphasis. Whereas Burke saw much danger in all the commotion and furor of the sublime, "Rancière treats the sublime as the sine qua non of political action, precisely because of its divisive nature" (Panagia, 2006, p. 88). From this perspective, one does not have to be a formal citizen in order to be heard and seen in a political sense. Those who are denied the status of citizen can break into the "consensual" system, interrupt this order, and assert themselves as a visible and speaking being. As Rancière (2006) says, "Politics means precisely this, that you speak at a time and in a place you're not expected to speak" (p. 5).

The task of politics therefore becomes something other than representing the unrepresented. Something much more ambitious, difficult, and radical is at work here. The task becomes theorizing the political in relation to the unrepresentable. As Panagia (2006) argues, non-status people "are unrecognizable, yet they demand acknowledgement. Lacking a proper name, they are unrepresentable, yet they demand equality” (p. 122).

\section{Border Lives}

Who is a non-status migrant? This is a surprisingly complex question. The simple definition provided by advocacy groups working for the rights of non-status people is that "non-status migrants are people who do not have the legal status that would allow them to live permanently in Canada" (Khandor, McDonald, Nyers, \& Wright, 2004). However, people can become "non-status" for many reasons. For example, their refugee claim and/or appeal may have been rejected; they may not have official identity documents; their sponsorship relationship may have broken down; their student visa, visitor's visa, or work permit may have expired; there may be a moratorium on deportations to their country of origin. Some scholars have begun using terms such as "uncertain status," "precarious status," and "gradations of status" to emphasize that one's legal position in the country—and hence one's relationship to rights, entitlements, access to services, obligations, responsibilities, and so oncannot always be talked about in strictly either/or terms. Instead, people often move in and out of status, and between different degrees of legal status. To speak of nonstatus in a legal sense is to consider a number of grey areas (Goldring, Berinstein, \& Bernhard, 2007). The point, however, is that all these areas are political, and they need to be examined critically. 
Technical definitions aside, in Canada, as elsewhere, many words are used to describe people without full legal immigration status. Non-status migrants are rarely portrayed in a positive or affirmative light, as fully formed subjects who are capable of autonomy, self-representation, and claim making. Critics who are opposed to this type of migration typically employ a pejorative discourse in order to define nonstatus people in terms of criminality ("illegals"), poor moral character ("queue jumpers"), or as a dangerous threat ("terrorists"). Others try to employ more neutral or humanitarian language, but here too the connotations are less than positive. In fact, it is extremely difficult to think of words to describe non-status people other than in terms of absence or lack: lack of documents ("undocumented"), lack of established travel arrangements ("irregular migrant"), lack of visibility ("clandestine workers"), lack of social status ("shadow population”), lack of security ("precarious status”), lack of humanity ("alien”). Academic writers similarly have been unable to use anything but the language of abjection and exclusion when speaking of nonstatus lives. Balibar (2000) describes them as the "excluded among the excluded"; Panagia (2006) calls them anomic: literally, "lacking a name”; Coutin (2000) says they occupy a "space of nonexistence"; De Genova (2002) describes the "space of forced invisibility, exclusion, subjugation, and repression" that non-status people must negotiate in order to survive (cf. Nyers, 2003).

The theme of lack is similarly echoed in interviews with non-status migrants living in Toronto and Montreal. ${ }^{3}$ One non-status person describes the situation facing members of the Latin American community in Toronto: "There are many people who live like ghosts.” People living this precarious life regularly describe the limited life opportunities afforded to them because of their lack of formal status:

"I am a lawyer, but if you don't have status then you are nobody.”
"A lot of employers are delighted to hear that you have no papers, because
they can overwork you and exploit you.”
"It really drains you that you have to work 12-hour shifts for very little
money. I used to be young. Now I feel so old.”

Non-status migrants live in constant fear of detention, deportation, and surveillance by the authorities. An activist in the Toronto Philippine community tries to be honest about the ultimate absence or lack involved in advocacy work for non-status people: "We're getting our people ready for deportation."

The experience of lack is produced in large part by the way non-status people experience borders. For non-status people the borderline is not just at physical entry points at ports, airports, and land crossings. Clearly, border politics are no longer limited (if they ever were) to the thin lines that separate domestic from foreign, here from there, us from them, the normal from the exceptional (Walker, 2006, p. 57). The border is a much thicker, more complicate site of practices; it is not "primarily a place, but a process" (Aas, 2005, p. 198), one that gets enacted wherever and whenever non-status people try to access social services provided by public officials. The border is therefore widespread and seemingly ubiquitous. For non-status people the border has literally become a "place where one resides" (Balibar, 2002, p. 83). It emerges places such as health care clinics, social housing cooperatives, schools, food banks, welfare offices, police stations, within a ubiquitous elsewhere. For people without status, everyday activities (working, driving, and going to school) are at risk of being transformed into criminal and illicit acts with dire consequences (De 
Genova, 2002, p. 427). Minor transgressions such as jaywalking across a city street can land the non-status migrant in immigration detention. Activists that do support work within the Toronto Immigrant Holding Centre report that many women are incarcerated there as a result of trying to access social services. There are many documented cases in Toronto of non-status women who end up in detention (often with their Canadian-born children) after they telephoned "911" and asked for emergency services. Women making a claim for police protection from domestic violence and abusive partners are placed in detention and eventually deported once their lack of formal status is discovered (Padgham, 2006). Here, we can see the highly discretionary-as opposed to law based-aspect of immigration law (Pratt, 2005, pp. 53-72), as city police make it a practice (although they are not directed to do so) to pass on details about immigration status the deportation arm of the Canadian state, the Canadian Border Services Agency. What begins as a rights claim for protection from domestic abuse ends up with the complainant being detained and deported.

Similar concerns about bordering practices have been directed to school officials, social housing buildings, and health clinics. By trying to access basic social services, non-status migrants end up triggering a deportation apparatus that implicates individuals and agencies well beyond those who directly work for Immigration Canada or the Canada Border Services Agency. For example, as a social worker who intervenes on behalf of a child experiencing abuse one may consider oneself to be acting in the best interests of the child. However, children aid societies are mandated to report abuse to the police. If the parents are without legal status then the police will inform immigration officials, and a deportation order is usually issued. What began as an act of compassion and protection ends up as deprivation of citizenship, as the child (who may well have been born in Canada and therefore be a citizen) is sent to the country of origin of his or her parents. Intentionally or not, social workers, school administrators, housing workers, and other providers of the benefits of social citizenship become functionaries of the deportation apparatus.

Acts of bordering are also acts of citizenship in that they are part of the process by which citizens are distinguished from others: visitors, strangers, outsiders, non-status people, and the rest. Like acts of citizenship, acts of bordering can be either deliberate or unintentional. Sometimes a mere visual cue to a memory of border experience is enough to enact a border once again.

I work at an agency where there is a very large Citizenship and Immigration Canada billboard right beside the main reception area. I find that sign to be one of the biggest barriers to providing services for nonstatus people. For people just walking in, even if they know that we offer services to non-status people, they see that billboard from Citizenship and Immigration Canada and just walk away. They remember the billboard as the same one they saw at the passport office and the Immigration Review Board: the places where they were rejected in the first place! This is a huge barrier to people thinking that they would be safe and treated any different from the institutions that had previously rejected them, making them non-status.

Or as a client support worker at a multicultural healthcare centre that provides services to non-status people complains: "My referrals are embarrassing. I refer 
people to more barriers. They report back to me consistently: 'I went to that agency you referred me to and the minute they asked me for my documents, I just walked out the door."”

\section{Autonomous Acts of Self-Representation}

While non-status people may experience the border as highly ubiquitous, it should be emphasized that this fact does not necessarily overcode the entirety of their lives. Despite the restrictions there still seems to be room for acts of citizenship. Many non-status people speak about life in a way that is not only about fear of authorities: "Many people live with fear. In one occasion the police got us. And in spite of that we go out. We do not live with fear." Soumya Boussouf from the Action Committee of Non-Status Algerians also emphasizes the multiple possibilities for living as a non-status person: "Even though you are a non-status person you do not even realize it. You are working; you have friends; you go out; you try to have a life despite all the barriers, despite everything — which is just normal, just human” (Lowry \& Nyers, 2003, p. 67).

In this context, the emergence of self-organized and autonomous action committees of non-status migrants is quite remarkable, not least for how they disrupt our expectations about what kind of action is possible by non-status migrants. In Canada, diverse communities of non-status migrants are organizing public campaigns with the aim of reframing the terms of their relationship to the political community. As one activist from the Toronto group No One Is Illegal explains:

\footnotetext{
One of the interesting trends is that so many different community groups are coming together to support themselves and each other. Like the Philippinos, the Bangladeshis, the Iranians, the Palestinians, the Algerians...we're really seeing a new trend of self-organized committees coming out of different communities. People in these communities are trying to figure out strategies for lobbying, mobilization, and public actions. This is something unique and we are seeing more and more of it.
}

The number of these self-organized and autonomous "action committees" of nonstatus migrants has indeed grown dramatically in Canada, especially since the aftermath of the 9/11 attacks. A partial list of the action committees includes: the Solidarity Across Borders coalition, the Coalition Against the Deportation of Palestinian Refugees, Action Committee of Pakistani Refugees, the Action Committee of Non-Status Algerians, the Human Rights Action Committee, Refugees Against Racial Profiling, and many others. The allies of these action committees are also numerous and diverse, but a growing number of them explicitly define themselves as allies in solidarity with, and not leaders of, this movement, and actively support the work of the non-status action committees. Again, a partial list of these groups includes the Ontario Coalition Against Poverty, Justice for Migrant Workers, the STATUS Coalition, the Vancouver Association of Chinese Canadians, and the autonomous No One Is Illegal groups in Toronto, Montreal, Vancouver, and other Canadian cities.

The emergence of non-status political action committees demonstrates that, like citizenship, migration can be understood as a strategy of becoming political. In a 
similar vein, Mitropoulos (2006) describes migration as "a strategy . . . undertaken in and against the cramped spaces of the global political economies of work, gender and desire, among other things, but a strategy for all that” (p. 8) Thinking about migration as a kind of strategy grants a certain autonomy to a phenomenon that is usually understood in relationship to various structural "push" and "pull” factors. What is sometimes called "autonomous migration" is an extra-legal form of selfdirected migration undertaken by individuals and communities as a survival strategy when states and other institutions no longer provide the conditions for an adequate quality of life (Rodriguez, 1996). This perspective sees migration as a complex social force that constitutes a social and political challenge to global controls on freedom of movement, albeit in ways that are only partially intentional and selfconscious (Mezzadra, 2004).

The idea of the "autonomy of migration" is easily confused with other concepts or processes. For example, autonomy here is not meant to imply a form of migration that is somehow independent of economic or other pressures and forces. Nor is it meant to imply that the migrant, in making their choice to move, is somehow the embodiment of a Kantian self-identical subject, making claims to cosmopolitan rights of hospitality. Instead, as Mitropoulos (2006) explains, the autonomy of migration means "that one does not concern oneself with the reasons why an other wishes to move across borders, simply put: it insists that the other is autonomous from oneself, particularly where one's self is most liable to assume the pose of deciding on such matters for an other, either because one's own belonging is not in question or as a means to prove that it should not be" (p. 10). The political acts of non-status migrant can therefore destabilize comfortable assumptions regarding political community that equate belonging with citizenship status. Perhaps the most radical consequence of this politics is the recasting of the terms, subjects, and spaces of the political itself. As Mitropoulos (2006) argues: "the concept of the autonomy of migration is an insistence that politics does not need to be the property of the state and those who-however implicitly and by dint of a claim to belong to it, as the subject that is proper to it (its property) — can claim to reserve for themselves the thought and action that is deemed to be properly political” (p.10).

One of the key means by which non-status people in Canada have asserted their autonomy as political actors is by reclaiming the discourse that defines their existence. This is an accomplishment that should not be underemphasized as there has been a significant change in the language and terminology used to describe them. There has been an important, albeit partial and contested, change in Canadian public discourse over the past decade from common references to "illegal immigrants" to a more regular use of the term "non-status." The charge of illegality is meant to undermine the moral character of certain types of migrants to Canada. The term "illegal" implies a breaking of the legal order, a violation of rule-following norms of behaviour, and an intention to commit a wrong. By contrast the term non-status signifies a set of meanings with a wider range of political possibilities.

As we saw above, non-status people may actually have a variety of statuses within the governmental order. The point of the term is not to designate a strict legal status, an either/or situation whereby one is either legal or not. Such logic is clearly out-ofstep with the complex way in which states and migrants negotiate residency, the right to work or study, refugee status, and other means through which people come to work, study, and live in Canada. The point is that the "non-status" are without any 
standing, rank, or position in a political order that privileges citizenship. The nonstatus migrant is of no consequence; they are "needed but unwelcome" (Appadurai, 2006, p. 44). The self-designation of "non-status," especially when it is articulated in public through words, images, or voice, is an articulation of a wrong. The demand of "status for all” is really a demand for "equality for all.” Equality here means equal access to the rights of social citizenship: health care, social welfare, and the rest. But it is also a demand for recognition and respect of the dignity of non-status people as human beings. To self-identify as non-status is to articulate a grievance to a community in which one has no legal or moral standing. In this way, the use of the term "non-status” can signal the emergence of a new political subjectivity.

\section{Acts of Regularization: Between City and Nation}

The key means by which the action committees have made claims to equality is through the demand for regularization. As a result of several years of cross-national networking between migrant rights groups and the action committees of non-status people, a series of common demands have emerged. These demands include an end to deportations, an end to the detention of migrants, immigrants, and refugees, and the abolition of "security certificates" (a measure in Canadian immigration law that allows non-citizens deemed to be a threat to "national security" to be held in detention indefinitely, without charge, and under secret evidence). The main demand, however, is that the Canadian government should introduce a program to regularize the status of all non-status migrants. These are ambitious, even audacious demands - and the political ground is tricky: historically the Canadian state has proved quite adept at excluding large numbers of non-status immigrants in its regularization programs.

While regularization programs are usually pitched as humanitarian acts of a compassionate government, the political reality is much more complex. Governments, for example, often introduce regularization programs when they are planning major changes to Canadian immigration law. Regularization programs allow people who were still in the clutches of the old system to be dealt with before new-and usually more restrictive and exclusionary-immigration procedures are introduced. In this way, regularization programs can go hand in hand with the imposition of tighter border regimes, more restrictive immigration controls, and harsher punishments on non-status immigrants. Moreover, the selection criteria used in regularization programs are part of the complex set of practices that work to produce and stabilize notions of citizenship and belonging. As a method of categorization, these criteria (such as criminality, medical inadmissibility, economic wealth, length of residency, level of "integration," family connections, or country of origin) separate those "worthy" of legal status, permanent residency, and eventual formal citizenship from those deemed undesirable, unworthy of status, and potentially dangerous to the national body politic. As a result, people with criminal records (however minor) and serious medical conditions (even if the illness originated in Canada) are likely excluded from regularization. In the end, the criteria for regularization are implicated in a nationalist production of fear, and reinforce a racialized discourse that constructs the immigrant as dangerous and diseased-to be screened, tested, monitored, and contained. 
The problems associated with making a claim for the state to regularize status are well known to the action committees and their allies. Increasingly, the demand for regularization is being directed at the level of the city as a way to sidestep many of the exclusions enabled by state level policies. This strategy has found its inspiration in developments in the United States, where many municipalities have developed "local citizenship" policies for non-status migrants. These include issuing driver licenses, providing in-state tuition rates for public colleges and universities, and even non-citizen voting in local elections (Varsanyi, 2006). Another source of inspiration has been the International Parliament of Writers' "cities of refuge" network, which offers hospitality and refuge to persecuted writers. The action committees of nonstatus migrants and their allies have begun to construct such a politics within Canadian cities, albeit with an important difference in how to approach sanctuary. The international cities of refuge network inspired by the IPW aims to advance freedom of expression and international solidarity by providing hospitality for persecuted writers. The aims of the city-based non-status campaigns are more ambitious. Instead of sanctuary being enjoyed by a single individual, hospitality would be shown to the tens of thousands of non-status people living in major Canadian cities. The struggle here is to envision emerging forms of international solidarity that advocate not only global freedom of movement and the right to cross borders, but also the right to stay where one already lives.

The action committees of non-status migrants have been active in campaigns to create sanctuary cities. The common tactic is to lobby municipalities to adopt some version of a "Don't Ask, Don't Tell” (DADT) policy with regard to immigration status. These policies prohibit municipal employees from asking about an individual's immigration status (“don't ask”), and also stop them from sharing this information with immigration or other government authorities (“don't tell”). Such a policy would ensure that municipal funds, resources, and workers would not be used to enforce federal or provincial immigration laws. A DADT municipal policy could ensure that city services are available to all city residents on the basis of residency and need, and without discrimination on the basis of immigration status. Since many non-status persons have difficulty obtaining official documents, the criteria of residency could act as a border. A more radical approach to realizing a sanctuary city would be to guarantee these services on the basis of one's presence within the city alone, and without the need to prove one's residency. Membership would be treated as a matter of social fact rather than legal status.

In the United States, over fifty municipalities have adopted some kind of DADT policy. In Canada, a DADT campaign was launched in Toronto in March 2004, with over forty community organizations as active participants. Groups in Vancouver and Montreal are considering similar campaigns. In a short period of time the Toronto DADT campaign has built momentum and received serious attention from the media, city counsellors, and the community at large. By 2007, both the police and the public school system in Toronto had formally endorsed a DADT policy. A DADT campaign advocates the provision of city services on the basis of residency, not immigration status. If successful, it will constitute a de facto regularization program. This is a canny recognition of the exclusions that are always built into state-level regularization programs. Those who were excluded from such a program would continue to be able to access health, education, police, and other city services 
without the fear of having their lack of status exposed and reported to immigration officials and border police.

To the extent that the city becomes a site of immigration policy-making-a prerogative reserved for the state-this may be a form of "municipal foreign policy" (Hobbs, 1994) that poses a serious challenge to the state as the site of a transformative politics. Is there the possibility that, as Derrida (2001) hoped with regards to the "cities of refuge" network, DADT cities will "reorient the politics of the state," "transform and reform the modalities of membership," and participate in the construction of "solidarities yet to be invented"? (p. 4).

\section{Mediating Acts of Citizenship}

To the extent that the demand for regularization of status is focused on recognition by state and other governmental authorities, is it really all that radical? Is this a politics that envisions formal state citizenship as its end goal? To be sure, the connections between status and the state are deep, right down to the level of language. Etymologies reveal that the word "status" and "state" share the same Latin root: stare-meaning "to stand." The association of "standing” with immobility, stasis, and lack of change implies a status quo, a conservatism regarding the standards of normality. Status, moreover, implies an implicit ranking or standing within society and so assumes a hierarchy of belonging. At the same time, however, a more disruptive reading of the root "to stand" is also possible. To stand also means to be seen, to become public, to be among the counted, to demonstrate one's existence and presence. Hence, standing requires a certain quotient of courage.

Investigating the moments when non-status people "act" as political allows us to move beyond the conservative elements of campaigns for status and focus on its potential for novel forms of political subjectification. The transformative dimension of acts of (non-)citizenship can be seen in the many public demonstrations and protest marches organized by the action committees and their allies. The presence of non-status people at a protest rally, for example, will have a mediating effect on the acts available to citizens also at the protest. It is quite normal for the rallies and marches organized for non-status rights to define themselves as "child friendly." As a result, activists with experience of, and perhaps even a preference for, direct action tactics have had to modify their own performances of citizenship. As Burman (2006) notes with regards to antideportation actions in Montreal: "Bold antipoverty activists - whom I have seen in other contexts antagonize the police-here consent to organizers' insistence that because of the precarious legal status of many of the demonstrators, participants must agree on a peaceful behavioural protocol” (p. 288). Out of similar concerns, speech makers at rallies have had to slow down their speeches in order to ensure that all protestors understand their political points. The act of citizens and non-status people raising their voices together in a public space to declare that "No One is Illegal" or "Status for All" or "So so so! Solidarité! Avec, avec, avec les Refugiés!” can also have the effect of opening new possibilities for collective political engagement.

The "nous" in "donnez-nous nos papiers," when uttered by citizens and noncitizens alike, changes the usual channels of nation-state-based 
community building and thus challenges the preexisting conduits of circulation...and makes visible the city as a node of differential temporalities and asymmetric orientations to the nation. (Burman, 2006, p. 290)

A flyer handed out during a Status for All march in Montreal in May 2007 underscored this point: "We march to refute the division between 'citizen' and 'noncitizen,' between 'good' and 'bad' immigrant, between 'guest' and 'permanent' workers, between those who deserve rights, and others who don't."

Must the acting subject be present in order for an act of citizenship to have occurred? The answer would seem to be no. Between June 16-25, 2005 hundreds of members of the coalition Solidarity Across Borders and their allies walked over $200 \mathrm{~km}$ from Montreal to the Parliament in Ottawa to demand the regularization of all non-status persons in Canada. A flyer handed out during the march, titled Why We Are Marching, declared that protesting non-status migrants "refuse to be invisible and silenced.” The flyer explained that the marchers were on their way to Ottawa in order to rectify a wrong that had been committed against them: "We are marching because there is no such thing as an 'illegal' human being, only unjust laws and illegitimate governments." The flyer also invoked the names of dozens of community members who had "been removed, detained, forced underground or forced into sanctuary.” Key among these names was Shamim Akhtar, a Pakistani refugee claimant and active member of Solidarity Across Borders and the Action Committee of Pakistani Refugees.

The March to Ottawa was an idea proposed by Akhtar in the summer of 2003. The Akhtar family was one of the most active families within the Action Committee, and worked to fight the deportation of hundreds of Pakistani non-status refugees from Montreal. Their asylum claim was rejected by the Canadian state, and the Akhtar family was deported in the summer of 2004. Akhtar, an activist within Solidarity Across Borders, proposed the idea of a March to Ottawa in the summer of 2003. Her removal from Canada notwithstanding, her agency left an impression that could not be erased by her deportation. As Burman (2006) explains: "When people are removed, their absence leaves an imprint; the intimates they have left behind restructure their everyday lives around that imprint” (p. 281). Burman argues that when the "imprint" of absence is transposed into a presence within the city, all sorts of possibilities emerge for "radical difference and hybridization" to emerge (p. 281).

The act of marching is deeply political. Etymologies of the verb "march" suggest a connection to Frankish word for "to mark out, delimit" and so is related to words such as borderland, boundary, and frontier. Surprisingly, one of the meanings of the verb march is "to have status." To march, therefore, not only implies a progressive and forward moving action; it is also related to the limits of the political, where insiders and outsiders, citizens and non-citizens are drawn. The non-status march is therefore a limit act of citizenship.

But is the emphasis on voice and audibility an overemphasis? Does it not retain and reproduce a certain liberal paradigm about citizenship which emphasizes audibility as opposed to visibility? Is it too much of a burden to have to be able to speak in public in order to be recognized as political? Is it not a problematic position to assume that everyone will know what it means to make a claim that can be recognized as such? In December 2003, No One Is Illegal established the Arts in Detention group for women and children being held in the Toronto Immigrant 
Holding Centre. The purpose of the art group is to "bring the messages of those incarcerated within its walls to the outside world in order to undermine nationalist assumptions of Canada as a multicultural, immigrant-welcoming nature.” The group also has as its aim to create "a space to open up discussion on the issues faced by non-status immigrants in Canada." ${ }^{4}$ Detention centres are designed to separate nonstatus people not only from the world on the outside, but from people within the facility as well. The art group was a special initiative that allowed detainees to actually engage, dialogue, and interact with one another. As Farrah Miranda points out: "The art group is the only thing at the detention centre that pulls all these women from different places to the same table, looking at each other, facing each other. It's really human” (Padgham, 2006, p. 181).

While life in detention makes the expression of political voice in any public way very difficult, the Arts in Detention group enabled expression through visual means. The artwork produced by the detainees was displayed to the broader public in May 2005, when the art produced by the women and children in detention was displayed as part of Toronto's annual Mayworks Arts Festival. This has given women detainees the opportunity to constitute themselves as cultural subjects. And since the artwork has been shown in galleries and reproduced in magazines and books, they are also becoming interlocutors in the debate about their condition. Much of their contribution to this debate is raising fundamental political questions about freedom, autonomy, and equality. Arts in Detention member Sima Zeheri explains: "A lot of their work is quite political, whether it's images of their homes and children or families, or explicit political messages and phrases. Often their art talks about wanting to stay in Canada, wanting to be free, stating that they are not criminals and that they shouldn't be in detention” (Padgham, 2006, p. 180). The art group had a restorative power Zeheri had not expected:

I thought it would be a lot grimmer, and it is, but there is more, too. There
were days when I was working as a volunteer with an NGO that provides
basic services at the detention centre and I would see forty people and
thirty of them would be in tears. But in the art group, you also see people
supporting each other, you see how they survive and keep up their sense of
humour and joy of life and optimism. There is almost a forgiveness of
everything that was happening to them. I feel awed and humbled by the
people inside, their courage and their perseverance. (Padgham, 2006, p.
181)

\section{Conclusions}

What does investigating the political acts of non-status migrants reveal about acts of citizenship? The focus on acts allows one to think about citizenship in terms other than debates over legal status, the distribution of rights, or identity politics (Joppke, 2007). Investigating acts of citizenship not only allows for these dimensions to be addressed and discussed, it also insists that the focus be on those moments-those acts-when. regardless of status, subjects constitute themselves as citizens, as those to whom the right to have rights is due. From the perspective of acts, when a group of non-status migrants make a demand for regularization, or protest against an upcoming deportation, or come out in public and shout "status for all" and "no one is 
illegal," we can hear these declarations as more than moral pleas for better, more humanitarian treatment. Rather, they can be heard as declarations that are generative of a political subjectivity. The process of subjectification in this context allows nonstatus groups to extract themselves from the hegemonic categories by which political identity is normally understood. It is quite a wonderful paradox to say that publicly self-identifying as a non-status migrant is to engage in an act of citizenship.

In his theorization of acts of citizenship, Isin (2008) suggests that three principles emerge when investigating citizenship. What can we learn about acts of citizenship from our discussion of the political activism of non-status migrants? The first is that acts of citizenship are not inherently exclusionary or inclusive, but can be interpreted as such through their consequences and effects. What are the effects of the acts of non-citizenship that have been discussed in this article? The key effect is that we are witnessing an interruption and transformation of the political. The lives of non-status people do not fit neatly into the frameworks of inclusion or exclusion, welcomed or rejected, dangerousness or victimage. Non-status migrants may be subjected to all of these discourses and practices, but they are also emerging as something more, something else, something other. They are not merely the citizen's Other, but also other claims-making and rights-taking political beings.

The second principle of studying acts of citizenship is that because acts produce subjects, finding an explicit motive or rationale for action is not a paramount concern. Subjects can enact themselves as political without articulating directly their reasons for acting as citizens. This dimension of acts of citizenship was demonstrated in several ways. Organizing street protests where both citizens and non-status people are active participants has the effect of tempering the speech acts of citizens. The Arts in Detention group allows for non-status detainees to express themselves politically without uttering a word. The “Don't Ask, Don't Tell” approach to sanctuary cities does not require any intentionality or even an admission of being non-status. Isin's second principle would seem to be confirmed by these examples.

There are, of course, some complex challenges involved in these acts. There is the issue that whereas citizens can speak with an assured voice and assume an audience within civil society, communities of non-status migrants can make no such assumptions. As a result they have had to take the strategy of interruption: they have had to organize their community, mobilize voices, stretch the norms of acceptable behaviour, and, at times, even break the law. There are also some serious limitations and dangers involved in the key demand for regularization. In addition to the problematic criteria, discriminations, and borderings involved in state initiated regularization programs, the sanctuary city approach has limits as well. ${ }^{5}$ In the first place, there is the concern that sanctuary cities of this kind operate on the basis of a secret. There is a definite sense of freedom of movement to be gained by the knowledge that interaction with municipal authorities will not inadvertently trip a borderline. However, the whole policy of DADT rests on the assumption of anonymity. Does this not reproduce the logic of silence, subterfuge, and secrecy that already determines much of the daily existence of non-status people? Nor does the demand for regularization address how the border is a temporal as much as a spatial experience. Time is a key factor in the logic of border management and control. Like all border experiences, the temporal dimension is experienced differently depending on one's class, status, race, gender, country of origin, and so on. For some, the border can involve delays, increased wait times, incarceration, and detention. For 
others, it can mean expedited movement and speedy processing for being a "trusted" traveller (Bhandar, 2004). Border time still affects people past their crossing into legal status. The point is that border times still affect racialized immigrant communities even when they are regularized: second- and third-generation immigrants still get regarded as "immigrants," citizens who are somehow foreign to the nation.

Finally, Isin asks us to consider the possibility that acts of citizenship can happen without being founded in law or responsibility. The politics of non-status migrants seem to take a paradoxical stance on this question. On the one hand, the most immediate concern is to pressure governments, both local and national, to regularize the legal status of all non-status migrants. While contesting territory within the zone of illegality, the movement nonetheless grounds its key demands within the law. On the other hand, these are clearly acts that call the law into question, and even break it. To become recognized as responsible it would seem that acts of irresponsibility must be undertaken. Street protests need to be organized; the offices of bureaucrats with authority to stop a deportation need to be occupied; claims must be made by those without the authority to speak; rights must be taken by those who have no right to have rights. In these ways and many others, politicized groups of non-status migrants are enacting themselves as citizens even when the law does not recognize them as such.

\section{Notes}

1 This article was originally published as a chapter in Acts of Citizenship, Engin F. Isin and Greg Nielsen, eds. London: Zed Books 2008, pp. 160-181.

2 This point was made by Rafael Samanez from the group, Esperanza del Barrio, at the public forum "Status for All! Reflections on Immigrant Justice Movements in Canada and the United States,” Citizenship Studies Media Lab, York University, Toronto, Canada, March 29, 2007.

3 Unless otherwise noted, quotations for this article are drawn from extensive focus group discussions and individual qualitative interviews with non-status immigrants, refugee and migrant rights activists, community agency workers, lawyers, and academics. These interviews were conducted in June-August 2004 and June-August 2005 in Toronto and Montreal. The non-status immigrants interviewed for this study represent a diverse group, and included members from the Algerian, Argentinean, Bangladeshi, Brazilian, Caribbean, Colombian, Iranian, Palestinian, and Philippine non-status communities in Toronto and Montreal.

4 Information on the Arts in Detention Group is available on the No One Is Illegal-Toronto website: http://toronto.nooneisillegal.org

5 For example, a DADT policy does not address the exploitation that non-status people face in areas such as employment. In fact, unscrupulous employers that exploit that labour of nonstatus people through overwork, dangerous conditions, and low pay may actually benefit from such a policy. After all, the physical and mental health of their workforce will likely improve because non-status people would be able access basic healthcare from the city.

\section{References}

Aas, K. (2005). Getting ahead of the game: Border technologies and the changing spaces of governance. In M. Salter \& E. Zureik, E., (Eds.), Global surveillance and policing: Borders, security, identity (pp. 194-213). Devon: Willam Publishing. 
Appadurai, A. (2006). Fear of small numbers: An essay on the geography of anger. Durham, NC: Duke University Press.

Balibar, E. (2000). What we owe to the sans-papiers. In L. Guenther \& C. Heesters, (Eds.), Social insecurity: Alphabet city no. 7 (pp. 42-43). Toronto: Anansi.

Bauder, H. (2006). And the flag waved on: Immigrants protest, geographers meet in Chicago. Environment and Planning A, 38(6), 1001-1004.

Beckman, L. (2006). Citizenship and voting rights: Should resident aliens vote? Citizenship Studies, 10(2), 153-165.

Bhandar, D. (2004). Renormalizing citizenship and life in fortress North America. Citizenship Studies, 8(3), 261-278.

Burman, J. (2006). Absence, "removal," and everyday life in the diasporic city: Antidetention/Antideportation activism in Montreal. Space and Culture, 9(3), 279-293.

Coutin, S. B. (2000). Legalizing moves: Salvadoran immigrants' struggle for U.S. residency. Ann Arbor, MI: University of Michigan Press.

De Genova, N. P. (2002). Migrant "illegality" and deportability in everyday life. Annual Review of Anthropology, 31, 419-447.

Derrida, J. (2001). On cosmopolitanism and forgiveness. New York, NY: Routledge.

Dolar, M. (2006). A voice and nothing more. Cambridge, MA: The MIT Press.

Editorial (2006). The sleeping giant. The New York Times, 29 April 2006, Section A, 10.

Forced Migration and Refugee Studies [FMRS] Program (2006). A tragedy of failures and false expectations: Report on the events surrounding the three-month sit-in and forced removal of Sudanese refugees in Cairo, September-December 2005. Cairo: The American University in Cairo (June).

Goldring, L., Berinstein, C., \& Bernhard, J. (2007). Institutionalizing precarious immigration status in Canada (CERIS Work Paper No. 61). Toronto: Centre for Excellence for Research on Immigration and Settlement.

Hobbs, H. (1994). City hall goes abroad: The foreign policy of local politics. Thousand Oaks, CA: SAGE.

Isin, E. (2008). Theorizing acts of citizenship. In E. F. Isin \& G. M. Nielsen (Ed.), Acts of Citizenship (pp. 15-43). New York, NY: Zed Books.

Joppke, C. (2007). Transformation of citizenship: Status, rights, identity. Citizenship Studies, 11(1), 37-48.

Khandor, E., McDonald, J., Nyers, P., \& Wright, C. (2004). The regularization of non-status immigrants in Canada, 1960-2004: Past policies, current perspectives, active campaigns. Unpublished report prepared for the STATUS Campaign, Toronto.

Lowry, M., \& Nyers, P. (2003). Roundtable report: "No one is illegal”: The fight for refugee and migrant rights in Canada. Refuge: Canada’s Periodical on Refugees, 21(3), 66-72.

McNevin, A. (2006). Political belonging in a neoliberal era: The struggle of the sans-papiers. Citizenship Studies, 10(2), 135-151.

Mezzadra, S. (2004). The right to escape. Ephemera, 4(3), 267-275.

Mitropoulos, A. (2006). Autonomy, recognition, movement. The Commoner, 11, 5-14.

Moulier-Boutang, Y. \& Grelet, S. (2001). The art of flight: An interview with Yann Moulier-Boutang. Rethinking Marxism, 13(3/4), 227-235.

Nyers, P. (2006). Taking rights, mediating wrongs: Disagreements over the political agency of non-status refugees. In J. Huysmans, A. Dobson, \& R. Prokhovnik, (Eds.), The politics of protection: Sites of insecurity and political agency (pp. 48-67). London: Routledge.

Nyers, P. (2003). Abject cosmopolitanism: The politics of protection in the anti-deportation movement, Third World Quarterly, 24(6), 1069-1093.

Padgham, O. (2006). Arts in detention: Creating connections with immigrant women detainees. In Deborah Barndt (Ed.), Wild Fire: Art as Activism (pp. 177-187). Toronto: Sumach Press.

Panagia, D. (2006). The poetics of political thinking. Durham, NC: Duke University Press.

Pratt, A. (2005). Securing borders: Detention and deportation in Canada. Vancouver: University of British Columbia Press.

Rancière, J. (2006). Our police order: What can be said, seen, and done. Le Monde Diplomatique (Oslo), August 8, 2006.

Rancière, J. (1999). Dis-agreement: Politics and philosophy. Minneapolis: University of Minnesota Press.

Rodriguez, N. (1996). The battle for the border: notes on autonomous migration, transnational communities, and the state. Social Justice, 23(3), 21-37.

Said, E. (2004). Beginnings: Intention and method. New York: Columbia University Press.

Walker, R. B. J. (2006). The double outside of the modern international. Ephemera, 6(1), 56-69.

Varsanyi, M. W. (2006). Interrogating “urban citizenship” vis-à-vis undocumented migration. Citizenship Studies, 10(2), 229-249. 